\title{
6. Vanuatu: Accountability from the Subsistence Age to the Internet
}

Age

\section{COMMINIHARY}

Vanuatu governments are not used to being held accountable. They act like they do not owe any explanation to the public about what they are doing. Rather than taking the initiative, successive Vanuatu governments seem to address significant issues only if they are forced by sustained public pressure in the private media to do so.

\section{MARIE-NOELLE FERRIEUX PATTERSON \\ President, Transparency Vanuatu, Port Vila}

$\mathrm{P}$ EOPLE living in westernised, First World countries have lived with a free media as part of the fabric of society for so long that it probably does not occur to them to ask themselves what it would be like not to have it. However, if you live in a country that does not have media freedom, or where media freedom is a very recent phenomenon, you perhaps understandably take it much less for granted. Even when a country's constitution guarantees such things as freedom of expression, as Vanuatu's does, that does not necessarily mean that free expression and FOI occurs automatically and nor does it mean it is accepted - even by those who signed the Constitution.

Vanuatu is not the only country that has had to move from the Subsistence Age to the Internet Age in a generation or two. Extreme change happening extremely rapidly is not easy for anyone to cope with so it can hardly be surprising that there are 'growing pains'. Moving from being a traditional closed 'chiefly' society where tribal 'big men' rule almost unquestioned to an open democracy with all the freedoms that implies, is bound to create friction.

Most people do not know what their own constitution says and do not understand well how their democratic system works, or is meant to work. Having said that, in some ways Vanuatu faces just as many practical problems as we 
do ideological issues. The simple broadcasting and receiving of information presents huge problems. For years, until it was fixed recently, people living in the outer islands (who represent more than half of the population of 240,000 people) had no way to receive radio broadcasts. Vanuatu has more than 80 islands, most of which are inhabited.

And even when it is possible, because there is no mains electricity available beyond the outskirts of the main towns of Port Vila, on Efate Island, and Luganville, on Santo Island, people must buy batteries for their radios. This means they need cash, something that is perpetually in short supply in the rural areas and smallest islands. Because there is no electricity outside of the towns, there is also no television reception and no Internet access.

There is also a very limited and unreliable distribution network to the outer islands that inhibits the delivery of newspapers. Air freight is expensive and shipping services are very erratic. The only development that has considerably increased communication and information has been the recent introduction of the mobile phone, with small solar chargers, allowing some form of communication in many islands, reportedly covering about 80 percent of the country

The government controls much of the flow of information within the country. The only local television channel is government-owned, so there is no analysis of government policy or actions, and certainly no criticism. There are no regular press conferences or media releases, or meaningful interviews with politicians where they are asked any difficult questions that might make them feel uncomfortable.

Vanuatu governments are not used to being held accountable. They act like they do not owe any explanation to the public about what they are doing. Rather than taking the initiative, successive Vanuatu governments seem to address significant issues only if they are forced by sustained public pressure in the private media to do so. And even then their responses are often wishy washy, avoiding the central issues.

A recent Coroner's report on the death of a re-captured prisoner in custody highlighted serious functional problems in the Police Force. In Vanuatu, both the police and the Mobile Force come under the control of one umbrella organisation.

This Coroner's report and the reactions (or lack of reaction) to it represent perhaps the most serious potential threat to the freedom of information and democracy. The members of the Vanuatu Mobile Force resisted in an extra- 
ordinary way when questioned by the New Zealand Supreme Court judge who was sitting as the Coroner. Witnesses were reportedly threatened and Coroner was temporarily evacuated from the country.

The Coroner's report also stated that the force did not appear to have any loyalty to the rule of law and to the country but only to themselves and this represented a threat to the country. This was a rather chilling reminder of what has happened in neighbouring countries like Fiji.

The politicians and media are all very cautious, and only one somewhat meek and mild response from the government eventually came out after the Coroner's report. So the potential threat to democracy is also a threat to freedom of information.

We had an attempted coup staged by the police in Vanuatu in 1997, allegedly to fight perceived widespread political or official corruption.

At the same time, there is no shortage of criticism of official misconduct in articles, editorials and 'letters to the editor', although letter writers often do not provide their names, and editors allow letters to be published anonymously. Radio talkback shows are more informed and more critical, expressing people's dissatisfaction with how their leaders are behaving. Transparency Vanuatu also publishes a half page every week in the national daily newspaper that has allowed many important issues to be raised. But despite all this, overall the public's tolerance of official misconduct often seems unlimited.

It would be fair to say that Vanuatu also needs a much higher standard of journalism, especially investigative journalism, whereby serious issues are properly looked into and followed up, and government officials are held to a much higher standard of accountability.

In some ways, journalistic reticence is understandable. In the past, journalists have been threatened and even deported. The Australian woman who owned Vanuatu's first private newspaper was deported in the 1980s by Father Walter Lini's government. The current publisher of the Daily Post newspaper has over the years been threatened and beaten up, and he was deported by former Prime Minister Barak Tame Sope, before returning to the country and eventually becoming a Vanuatu citizen.

The publisher, Marc Neil-Jones, was assaulted recently because of criticisms he wrote about the Vanuatu Mobile Force and the Correctional Services Department. Not long ago, a young pregnant Vanuatu journalist lost her baby after being assaulted by someone who was not happy with her reporting. 
There were no consequences for any of the people involved in these incidents. No investigations, no charges, no prosecutions.

At election times almost no coverage appears in the media about the individual candidates or their policies, or the backgrounds of those who have already been discredited in the Ombudsman's public reports.

On the other hand, as has been repeatedly mentioned, in the Pacific people tend to be passive in general and accept authority without too much question. Furthermore, they hesitate to challenge each other in their small communities. The 'wantok' system has been acknowledged for the limitations it creates in matters such as prosecution of alleged wrongdoers.

We are even handicapped by the fear among most people that they can somehow be harmed by 'black magic' or nakaimas and other superstitions. Transparency Vanuatu from its onset has recognised this situation and has put its priorities on the awareness of citizens, going out in all the islands to do workshops on legal literacy and introducing civic education in the curriculum. We also work regularly on media projects with journalists and the people.

In summary, nothing will change unless there is a fundamental change of heart within official circles - and I am tempted to ask when or where has that ever happened? And this needs to be accompanied by more rigorous investigative journalism, and perhaps most importantly of all, an increasing appetite from the general public for a higher standard of government at all levels.

This, of course, all takes time, and in Vanuatu, it is likely to take decades. Even modernised, westernised countries that were industrialised more than two hundred years ago are still evolving and maturing and we are still unearthing one corruption scandal after another, whether that be political, commercial, sporting or personal.

But change has happened elsewhere, so I am optimistic that it can also occur in a small, recently born country like Vanuatu. If I wasn't, I would not be here.

Marie-Noelle Ferrieux Patterson is president of Transparency International in Port Vila. She gave an earlier version of this address at the UNESCO World Press Freedom Day Conference at the University of Queensland, Brisbane, 1-3 May 2010 as part of a 'Media freedom in the Pacific' panel. transparency@vanuatu.com.vu 
Copyright of Pacific Journalism Review is the property of Auckland University of Technology and its content may not be copied or emailed to multiple sites or posted to a listserv without the copyright holder's express written permission. However, users may print, download, or email articles for individual use.

http://www.aut.ac.nz/depts/commstud/journ/pjrsubs.shtml 